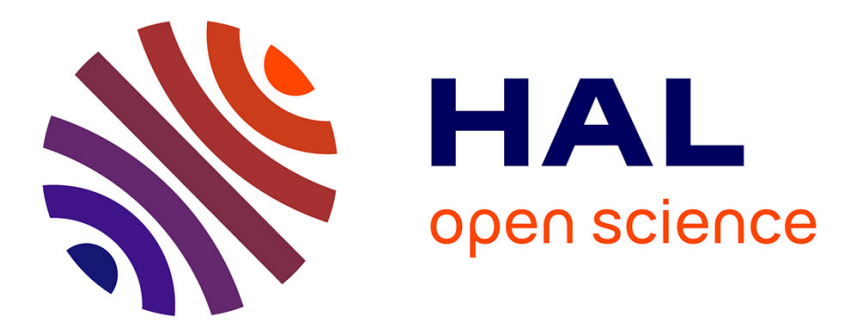

\title{
Physical properties of electrodeposited CIGS films on crystalline silicon: Application for photovoltaic hetero-junction
}

H. Saïdi, C. Ben Alaya, M. F. Boujmil, B. Durand, J.-L. Lazzari, M. Bouaïcha

\section{- To cite this version:}

H. Saïdi, C. Ben Alaya, M. F. Boujmil, B. Durand, J.-L. Lazzari, et al.. Physical properties of electrodeposited CIGS films on crystalline silicon: Application for photovoltaic hetero-junction. Current Applied Physics, 2019, 20 (1), pp.29 - 36. 10.1016/j.cap.2019.09.015 . hal-03141578

\author{
HAL Id: hal-03141578 \\ https://hal.science/hal-03141578
}

Submitted on 15 Feb 2021

HAL is a multi-disciplinary open access archive for the deposit and dissemination of scientific research documents, whether they are published or not. The documents may come from teaching and research institutions in France or abroad, or from public or private research centers.
L'archive ouverte pluridisciplinaire HAL, est destinée au dépôt et à la diffusion de documents scientifiques de niveau recherche, publiés ou non, émanant des établissements d'enseignement et de recherche français ou étrangers, des laboratoires publics ou privés. 


\section{Journal Pre-proof}

Physical properties of electrodeposited CIGS films on crystalline silicon: Application for photovoltaic heterojunction

H. Saïdi, C. Ben Alaya, M.F. Boujmil, B. Durand, J.L. Lazzari, M. Bouaïcha

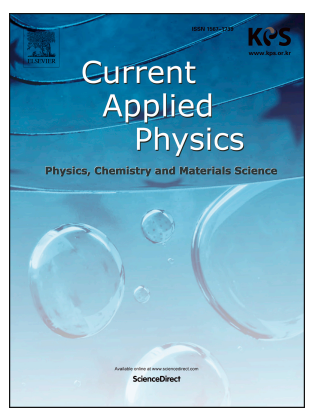

PII:

S1567-1739(19)30247-0

DOI: https://doi.org/10.1016/j.cap.2019.09.015

Reference: CAP 5062

To appear in: Current Applied Physics

Received Date: 17 July 2019

Revised Date: 17 September 2019

Accepted Date: 25 September 2019

Please cite this article as: H. Saïdi, C. Ben Alaya, M.F. Boujmil, B. Durand, J.L. Lazzari, M. Bouaïcha, Physical properties of electrodeposited CIGS films on crystalline silicon: Application for photovoltaic heterojunction, Current Applied Physics (2019), doi: https://doi.org/10.1016/j.cap.2019.09.015.

This is a PDF file of an article that has undergone enhancements after acceptance, such as the addition of a cover page and metadata, and formatting for readability, but it is not yet the definitive version of record. This version will undergo additional copyediting, typesetting and review before it is published in its final form, but we are providing this version to give early visibility of the article. Please note that, during the production process, errors may be discovered which could affect the content, and all legal disclaimers that apply to the journal pertain.

() 2019 Published by Elsevier B.V. on behalf of Korean Physical Society. 


\section{Graphical abstract}

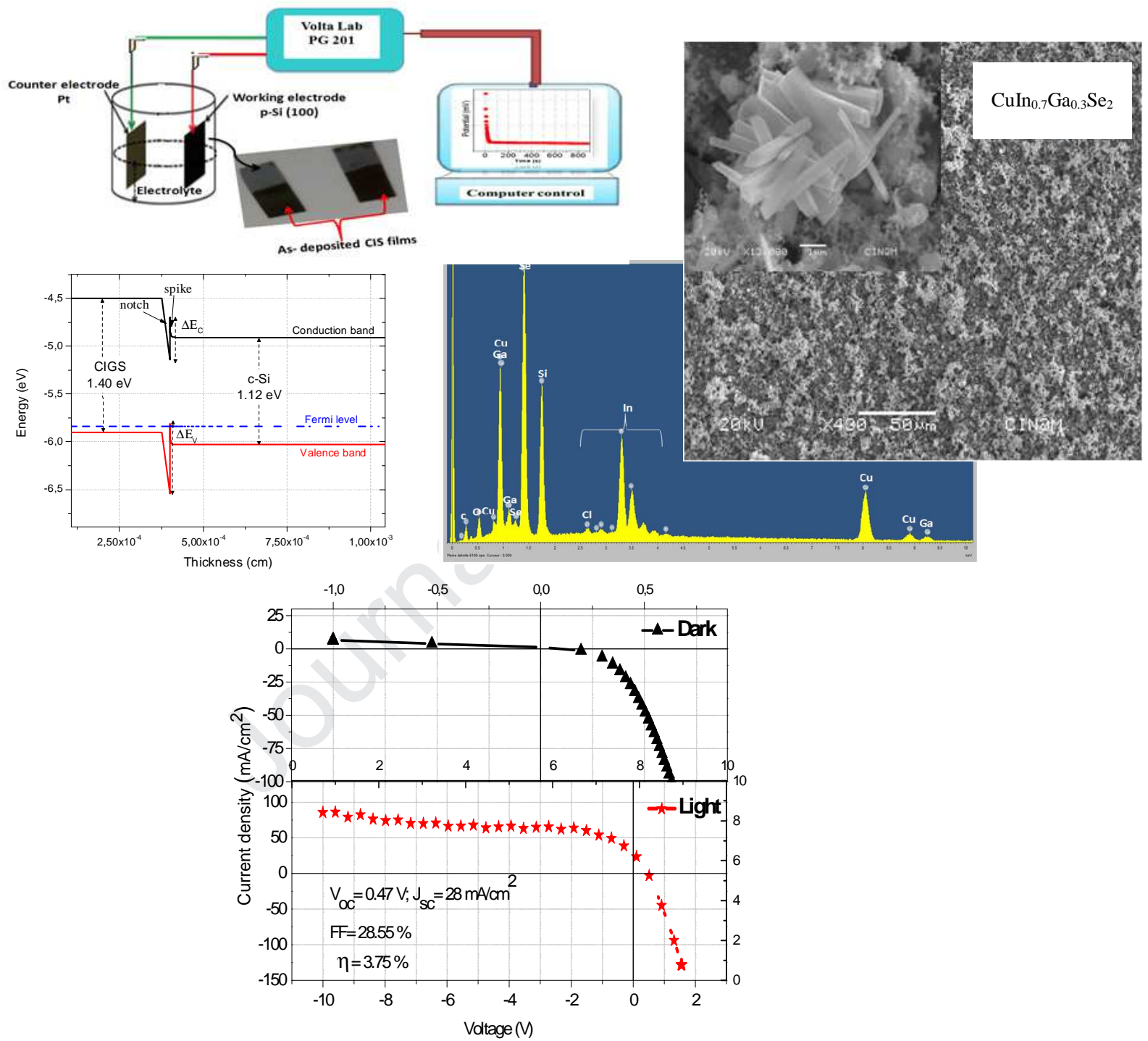




\title{
Physical properties of electrodeposited CIGS films on crystalline silicon:
}

\section{Application for photovoltaic heterojunction}

\author{
H. Saïdi ${ }^{\text {a }}$ C. Ben Alaya ${ }^{\mathrm{a}}$, M. F. Boujmil ${ }^{\mathrm{a}}$, B. Durand ${ }^{\mathrm{b}}$, J. L. Lazzari ${ }^{\mathrm{c}}$ and M. Bouaïcha ${ }^{\mathrm{a} *}$ \\ a'Laboratoire de Photovoltaïque, Centre de Recherches et des Technologies de l'Energie, Technopole de Borj- \\ Cédria, BP 95, Hammam-Lif, 2050 Tunis, Tunisia \\ ${ }^{\mathrm{b}}$ CIRIMAT, CNRS, INPT, Université de Toulouse, 118, Route de Narbonne, 31062 Toulouse cedex 9, France \\ 'Aix Marseille Univ, CNRS, CINaM (Centre Interdisciplinaire de Nanoscience de Marseille), Case 913, Campus \\ de Luminy, 13288 Marseille cedex 9, France
}

*Corresponding author: Mongi.Bouaicha@crten.rnrt.tn; Phone: (+216) 79325160; Fax: (+216) 79325934

\begin{abstract}
P-type CIGS (CuIn $\left.{ }_{1-x} \mathrm{Ga}_{\mathrm{x}} \mathrm{Se}_{2}\right)$ thin films are electro-deposited on a p-type c-Si substrate with a galvanostatic mode to form CIGS(p)/c-Si(p) hetero-junction. The Ga content is varied up to $\mathrm{x}$ $=30 \%$. The physical properties of formed CIGS films are characterized by XRD, SEM, EDS and UV-Visible spectroscopy. With $\mathrm{x}=30 \%$, we obtain a single chalcopyrite phase of CIGS with a tetragonal crystal structure, a high crystallinity, an orientation toward the (112) direction and a band gap energy of $1.40 \mathrm{eV}$.

AM1.5 J-V performed on the $\mathrm{CuI}_{0.7} \mathrm{G}_{0.3} \mathrm{Se}_{2} / \mathrm{c}-\mathrm{Si}$ hetero-junction reveals interesting photovoltaic parameters with an efficiency of $3.75 \%$. In addition, using the energy diagram of the hetero-junction calculated with the Anderson model, we show that it could play a dual role when combined to a c-Si cell in a $\mathrm{Ag}-\mathrm{Al} / \mathrm{c}-\mathrm{Si}\left(\mathrm{n}^{+}\right) / \mathrm{c}-\mathrm{Si}(\mathrm{p}) / \mathrm{CIGS}(\mathrm{p}) / \mathrm{Al}$ new architecture. Therefore, in addition to its interesting photovoltaic parameters, this hetero-junction can substitute the BSF.
\end{abstract}

Keywords: CIGS; Silicon, Electro-deposition, Hetero-junction. 


\section{Introduction}

Nowadays, photovoltaic (PV) energy plays a key role in renewable energy (RE) scenarios. The conversion efficiency of silicon solar cells is being $25.8 \%$ at a laboratory scale and a stability of 20 years [1]. Improving solar cell efficiencies while simultaneously lowering its cost is an essential challenging aim in R\&D (Research and Development) in photovoltaic. In the last few years, thin film solar cells based on polycrystalline chalcopyrite materials (I-III$\mathrm{VI}_{2}$ ), have received great deal of attention due to their versatile optical and electrical properties [2]. Copper Indium Gallium Diselenide $\mathrm{Cu}(\mathrm{In}, \mathrm{Ga}) \mathrm{Se}_{2}$ (CIGS) with a chalcopyritetype structure has proven to be one of the prominent candidates to compete with the efficiency and stability of conventional crystalline silicon cells, because of its high light absorption coefficient, lower materials cost and great stability [3-4]. Additionally, CIGS has a direct band gap which can be varied from 1.02 to $1.60 \mathrm{eV}$ by increasing the Ga proportions ratio from 0 to 1 [5]. Further, solar cells based on CIGS thin films have the highest efficiencies among second generation photovoltaic devices with a record laboratory scale efficiency reaching about 22.6\%) [1]. Many efforts have been invested to obtain a low cost CIGS absorber layer by different approaches including chemical and physical methods [6-8]. Electrochemical deposition techniques of CIGS thin films have been extensively investigated [9]. Especially, the one-step electro-deposition method (ECD) is competitive, economic and convenient. Moreover, this approach has many advantages such as; high deposition speed, low processing cost, no vacuum system required and the use of a large area of substrate at room temperature [10]. The cell efficiencies based on CIGS thin films fabricated by the ECD process are close to $7 \%$ for $30 \times 30 \mathrm{~cm}^{2}$ surface area and about $10 \%$ for laboratory-scale device modules [11]. 
Bifacial solar cells can use direct and diffuse sunlight to create electric energy from both front and back surfaces of the cell. This kind of device provides high-efficiency cell design and it is competent of generating more electrical power per cell by absorbing photons from both sides of the device [12]. In a previous work [13] we reported on the physical properties of CIS/c-Si hetero-junction with a conversion efficiency of $\sim 0.41 \%$. Nevertheless, the efficiency of such cell can be improved with good reproducibility by widening the band gap to an optimal value of $1.5 \mathrm{eV}$ that could be adjusted through $\mathrm{Ga}, \mathrm{Al}$ and/or $\mathrm{S}$ incorporation in the CIS matrix.

The partial substitution of $\mathrm{In}^{3+}$ by $\mathrm{Ga}^{3+}$ ions is important in increasing the band gap to values between $1.04 \mathrm{eV}$ of $\mathrm{CuInSe}_{2}$ and $1.68 \mathrm{eV}$ of $\mathrm{CuGaSe}_{2}$ and to reach enhanced conversion

efficiency [14]. In other hand, it is necessary to optimize the atomic ratio $x=\frac{G a}{I n+G a}$ in order to obtain high quality of fabricated layers. The effect of $\mathrm{Ga}$ content on the properties of chalcopyrite $\mathrm{CuIn}{ }_{1-\mathrm{x}} \mathrm{Ga}_{\mathrm{x}} \mathrm{Se}_{2}$ thin films have been investigated by many authors [15]. The best CIGS solar cell efficiency was obtained with a $30 \%$ Ga-content.

The main emphasis and purpose of this work is the investigation of Ga content on the physical properties of the CIGS film fabricated on crystalline silicon substrate. Furthermore, these physical properties were used to analyze and discuss the electrical performances of fabricated CIGS(p)/c-Si(p) hetero-junction solar cell deduced from AM1.5 current density - voltage characterization.

\section{Experimental details}

$\mathrm{CuIn}_{1-\mathrm{x}} \mathrm{Ga}_{\mathrm{x}} \mathrm{Se}_{2}$ thin films with $\mathrm{x}$ ratio ranging from 0.0 to 0.3 were electro-deposited on monocrystalline silicon substrates using a Volta Lab potentiostat/galvanostat (PGP 201) connected to a two-electrode cell. We used boron doped p-type monocrystalline silicon wafers with a (100) crystal orientation, a thickness of $525 \pm 25 \mu \mathrm{m}$ and a resistivity in the 1-2 $\Omega . c m$ range. The set-up contains the silicon substrate as the working electrode and a platinum 
counter electrode. The electro-deposition mixture is formed by $3 \mathrm{Mm}$ of $\mathrm{CuCl}_{2}, 3 \mathrm{Mm}$ of $\mathrm{InCl}_{2}, 0.3-0.9 \mathrm{Mm}$ of $\mathrm{Ga}_{2} \mathrm{O}_{3}, 8 \mathrm{Mm}$ of $\mathrm{SeO}_{2}$ and $0.1 \mathrm{M}$ of sodium citrate (complexing agent) in de-ionized (DI) water. The $\mathrm{pH}$ of the bath has been adjusted to 1.65 via the addition of hydrochloric acid $(\mathrm{HCl})$. During the electro-deposition, the solution was stirred and a constant current density of $10 \mathrm{~mA} \cdot \mathrm{cm}^{-2}$ was applied during a deposition time of 10 minutes at room temperature.

Before experiment, the silicon wafers were ultrasonically cleaned with acetone, ethanol and DI water. Then, they are dipped into dilute hydrofluoric acid (HF, 5\%) solution for 1 minute in order to remove the native $\mathrm{SiO}_{2}$ insulating film to permit the electro-deposition of CIGS on the silicon substrates. After electro-deposition, all samples were annealed in a nitrogen atmosphere at optimized temperature of $350{ }^{\circ} \mathrm{C}$ for 5 min by an infrared Rapid Thermal Processing (RTP). The RTP annealing permits a formation of an excellent crystallized CIGS film [13-16]. Hall effect characterization at ambient temperature (300 K) confirms the p-type nature of CIGS films. Thus, for the $\mathrm{CuIn}_{0.7} \mathrm{Ga}_{0.3} \mathrm{Se}_{2}$ film, we obtained a concentration of majority carriers of $3.5510^{16} \mathrm{~cm}^{-3}$, a conductivity of $3.73 \Omega^{-1} . \mathrm{cm}^{-1}$ and a mobility of 656 $\mathrm{cm}^{2} \cdot \mathrm{V}^{-1} \cdot \mathrm{s}^{-1}$

The structural properties of elaborated CIGS thin films were studied by means of X-ray diffraction (XRD) analysis using an automated Bruker D8 advanced diffractometer with a $\operatorname{CuK}_{\alpha}(\lambda=1.540 \AA)$ radiation. Surface morphology of the samples was characterized by a Scanning Electron Microscope (SEM) JEOL JSM-5910, with an accelerating voltage of 20 kV. Energy Dispersive Spectroscopy (EDS), as well as the UV-Visible-NIR LAMBDA 950 spectrophotometer were used to determine chemical compositions and optical properties, respectively. Thermal evaporation instrument was further used to deposit a Back and grid front aluminum (Al) contacts. Then, samples were heated in argon atmosphere using RTP furnace at specific annealing temperatures during $15 \mathrm{~min}$ (i.e.; $630{ }^{\circ} \mathrm{C}$ for the back and $250 \mathrm{C}^{\circ}$ 
for the grid front Al contacts). AM1.5 short current-voltage characterization of the fabricated photovoltaic cell was measured by a digital source meter (Keithley Instruments Inc., Model $2400)$ in the dark and under AM1.5 (100 mW.cm $\left.{ }^{-2}\right)$ illumination.

\section{Results and discussion}

We plot in Fig. 1 XRD patterns of $\mathrm{CuIn}_{1-\mathrm{x}} \mathrm{Ga}_{\mathrm{x}} \mathrm{Se}_{2}$ films with different gallium percentages. For undoped sample $(\mathrm{x}=0)$, in addition to the Si (100) diffraction peaks, we notice three main diffraction peaks at approximately $26.56^{\circ}, 44.26^{\circ}$ and $52.40^{\circ}$ assigned respectively to (112), (204) (220) and (116) (312) plans of the well-identified CIS chalcopyrite phase (Ref. JCPDS 40-1487). After Ga doping, we observe a high $2 \theta$ shift of CIS peaks. This shift indicates the incorporation of Ga in CIS matrix and hence a formation of the quaternary $\mathrm{CuIn}_{1-\mathrm{x}} \mathrm{Ga}_{\mathrm{x}} \mathrm{Se}_{2}$ which is consistent with the standard reported values for CIGS (JCPDS NO. 03-065-7027). This result was demonstrated by several researchers [17]. Furthermore, the crystal phase of $\mathrm{CuIn}_{1-\mathrm{x}} \mathrm{Ga}_{\mathrm{x}} \mathrm{Se}_{2}$ films is affected by varying the gallium content. In fact, the (112) peak intensity decreases clearly with increasing gallium concentration especially for the specimens obtained at $0.1 \leq \mathrm{x}<0.3$, so a noticeable increase in the full width at half maximum FWHM (table.1) can be noticed, indicating a low crystallization of films. Whereas, increasing Ga content to $30 \%$ XRD pattern shows the formation of a single chalcopyrite tetragonal structure with a strong and preferential orientation along the (112) direction. This provides that $\mathrm{Ga}$ in higher concentration improves crystallization. In order to confirm this result, we investigate the effect of gallium composition on the preferential orientation in fabricated films. As reported in Fig. 2, the (112) peak relative intensity has a maximum value when the substitution rate is $30 \%$.

The low intensity of (112) peaks for samples synthesized with low percentage of gallium suggests their worse crystallinity, which may be attributed to the large compositional 
deviation from the stoichiometry and/or to structural disorder introduced in the chalcopyrite crystal lattice by inhomogeneous gallium incorporation.

Improved crystallinity was checked by the change in crystallite sizes which were calculated from the main peak intensity by the Scherrer formula expressed by Eq. (1) [18]:

$$
D=\frac{\mathrm{k} \lambda}{\beta \cos \theta}
$$

Where $\lambda$ is the $\mathrm{X}$-ray wavelength of $\mathrm{CuK} \alpha$ line $(\lambda=1.540 \AA), \theta$ is the Bragg angle and $\beta$ is the values of the FWHM of the (112) peak.

According to calculated values of grain size given in table 1 , we guess that the average crystallite size is changed by varying the relative amounts of gallium. In addition, the largest crystallite with mean grain diameter of about $82.50 \mathrm{~nm}$ is obtained for the CIGS thin film with high $\mathrm{x}$ ratio. This result confirms the XRD analysis which shows an improvement in crystallinity at this corresponding ratio.

As mentioned above, Ga incorporation causes a shift of the diffraction peaks to higher Bragg angles, in particular the highest peak (112), which causes a change of the lattice parameters a and $\mathrm{c}$. Indeed, the variation of the two lattice parameters a and c with gallium composition given in figure 3 is found to be approximately linear as the latter is increased from zero $\left(\mathrm{CuInSe}_{2}\right)$ to one $\left(\mathrm{CuGaSe}_{2}\right)$, which is in agreement with Vegard law [19]. Therefore, CIGS films prepared using one step electro-deposition process is very close to the perfect tetragonal structure for which the lattice distortion is $\mu=c / a \simeq 2$ ) [20]. The variation of the lattice constants as a function of $\mathrm{x}$ in CIGS thin films is given by the following two equations:

$$
a_{C u I n}(1-x) G a_{x} S e_{2}=5.78 \AA-0.17 \AA x
$$




$$
c_{C u I n}{ }_{(1-x)} G a_{x} S e_{2}=11.61 \AA-0.57 \AA x
$$

These expressions are in good agreement with those reported in the literature, e.g. $a=5.783 \AA$ $0.171 \AA$ and $c=11.618 \AA-0.586 \AA \mathrm{x}[21]$.

As shown in Fig. 3 and table.1, the lattice parameters a and c of all CIGS films were found to decrease when the percentage of gallium rises. This reduction could be explained by the small ionic radius of $\mathrm{Ga}(\mathrm{r}(\mathrm{Ga})=1.81 \AA)$ compared to $\mathrm{In}(\mathrm{r}(\mathrm{In})=2 \AA)$, an effect which was already known and widely studied in the literature [22].

The micro-strain $(\varepsilon)$ developed in CIGS thin films is calculated using the following relation: [23]

$\varepsilon=\frac{\beta}{4 \tan \theta}$

As reported in table 1, values of $\varepsilon$ decreases from $0.275 \%$ for sample synthesized with low percentage of $\mathrm{Ga}(\mathrm{x}=0.1)$ to $0.177 \%$ for deposited film with high gallium rate $(\mathrm{x}=0.3)$. This is attributed to a reduction in defect centers in the structure and the improvement in sample crystallinity. Therefore, a Ga composition of 0.3 appears beneficial to obtain interesting structural quality of such films.

The surface morphology of deposited CIGS layers is depicted in Fig. 4. Different morphologies can be observed prior and after Ga doping. In fact, micrograph (Fig. 4a) reveals a homogeneous surface with a uniform and dense distribution of aggregates composed of small rounded grains. For compounds prepared with low gallium content (Figs. $4 b$ and 4c), the surface morphology is deteriorated displaying grains/particles with uneven sizes which leads to non-homogeneous surface. However, a more consistent variation in morphology is observed in insert of Fig. $4 \mathrm{~d}$ when the Ga content is $30 \%$. The surface of the film appears to be more homogenous and formed by aggregates consisting of larger size crystals having rod- 
like shapes. The length of the latter varies from 1 to $3 \mu \mathrm{m}$. Therefore, the crystallinity of the CIGS films is noticeably improved with increasing Ga content, especially at 30\%. In addition, the grain size became larger, which is consistent with XRD analysis.

Fig. 5 shows a typical EDS spectrum for $\mathrm{CuIn}_{1-\mathrm{x}} \mathrm{Ga}_{\mathrm{x}} \mathrm{Se}_{2}$ films with $\mathrm{x}=0 \%$ and $\mathrm{x}=30 \%$. The chemical composition of CIS $(\mathrm{x}=0 \%)$ layer characterized by EDS (Fig. 5a) reveals the presence of copper, indium and selenium elements. The compositional analysis of this CIS film is summarized in table 2. Otherwise, as shown in Fig. 5b, in addition to copper, indium and selenium elements, we note the appearance of new peaks assigned to the gallium element. This confirms the Ga incorporation in CIS film and the formation of a single quaternary $\mathrm{CuIn}_{0.7} \mathrm{Ga}_{0.3} \mathrm{Se}_{2}$ phase that has been already mentioned by XRD studies. As well as that, the presence of other elements such as residual oxygen and carbon may be due to interface and surface contamination however silicon is attributed to the substrate.

The compositional analysis of $\mathrm{CuIn}_{1-\mathrm{x}} \mathrm{Ga}_{\mathrm{x}} \mathrm{Se}_{2}$ films with various $\mathrm{Ga}$ content is summarized in table 2. We notice that specimens synthesized with $10 \%$ and $20 \%$ of Ga contents are not stoichiometric and the $\mathrm{x}$ ratio is less than one. While, increasing gallium content above $30 \%$, the elementary composition tends to improve in quaternary CIGS thin film and the best stoichiometry was achieved.

The optical properties (absorption coefficient, band gap energy...) of quaternary CIGS thin films depend on the relative of component element and especially on the $\mathrm{x}$ ratio. In addition, the partial substitution of $\mathrm{In}^{3+}$ by $\mathrm{Ga}^{3+}$ ions leads to increase the band gap energy (for heterostructure with monocrystalline silicon) and hence to improve the opto-electrical properties of materials [24].

From the diffuse reflection spectra $\mathrm{R}(\lambda)$, we have assessed the absorption coefficient of $\mathrm{Cu}$ $\left(\mathrm{In}_{1-\mathrm{x}} \mathrm{Ga}_{\mathrm{x}}\right) \mathrm{Se}_{2}$ layers using the Kubelka-Munk function $\mathrm{F}(\mathrm{R})$, determinate with respect to reflectivity of dense films $\left(\mathrm{R}=\mathrm{R}_{\infty}\right)[15]$. 


$$
F(R)=\frac{(1-\mathrm{R})^{2}}{2 \mathrm{R}}
$$

A plot of $[\mathrm{F}(\mathrm{R}) h v]^{2}$ vs. $h v$ as illustrated in Fig. 6 is extrapolated to be a straight line portion of the absorption edge whose intercepts the energy axis giving the optical band gap of the CIGS films. As a result, we obtain a shift of the absorption edges towards higher energies when the Ga composition increases. Hence, we found that value of the band gap energy rises from 1.01 $\mathrm{eV}$ to $1.40 \mathrm{eV}$ when gallium proportion rises from 0 to $30 \%$ (see inset graph). Similarly, Cao Jie et al. [25] obtained a value of $1.38 \mathrm{eV}$ at the same Ga content. However, we notice that in other works [26], reported values are below $1.2 \mathrm{eV}$. In fact, the increase in direct band gap with change of gallium rate is studied by many investigators [27-28]. According to these researches, authors reported two main causes. The first reason might be linked to differences between the electro-negativity of the $\mathrm{In}^{+3}$ and $\mathrm{Ga}^{3+}$ ions which leads to broadening of valence/conduction bands inducing the increase of the gap. The second one is related to an important distortion of the tetragonal lattice in films generated by Ga- addition. In the present study, we attribute the increase of the optical band gap to two major effects; the improvement in crystallinity and the reduction of defects like strain and dislocations density, which provide less contribution beneath the absorption edge in this corresponding substitution rate. This result is confirmed by XRD analysis. Furthermore, the increase of optical band gap to $1.4 \mathrm{eV}$ improves the open circuit voltage $\mathrm{V}_{\mathrm{OC}}$ of the CIGS/c-Si heterojunction by increasing the difference between the quasi Fermi levels during illumination.

As previously highlighted in micro-structural and optical analysis, the sample with $30 \% \mathrm{Ga}$ contents exhibits a better crystallization and has a more propitious band gap compared to our other fabricated films. To achieve the fabrication of the based hetero-junction solar cell, we thermally evaporate aluminum to form back and front (grid) contacts to perform dark and 
AM1.5 illumination characterizations. To a better understanding of such characterizations, we simulate the energy diagram of the CIGS(p)/c-Si(p) hetero-junction using the Anderson model. Result is plot in figure 7(a). We notice that in these calculations, the Anderson model uses the electron affinity and band gap values of both semiconductors to calculate offsets of conduction and valence bands $\left(\Delta \mathrm{E}_{\mathrm{C}}\right.$ and $\left.\Delta \mathrm{E}_{\mathrm{V}}\right)$. As depicted in figure $7(\mathrm{a})$, we observe a "spike" and "notch" at the interface. These simulation were performed with $\mathrm{x}=30 \%$. We notice that since $\mathrm{N}_{\mathrm{A}}(\mathrm{Si})$ is in the round of $10^{+15} \mathrm{~cm}^{-3}$, and obtained $\mathrm{N}_{\mathrm{A}}(\mathrm{CIGS})$ from Hall effect measurements is $3.5510^{+16} \mathrm{~cm}^{-3}$, this hetero-junction can play a double role when it is used in c-Si bifacial solar cells $\left(\mathrm{Ag}-\mathrm{Al} / \mathrm{c}-\mathrm{Si}\left(\mathrm{n}^{+}\right) / \mathrm{c}-\mathrm{Si}(\mathrm{p}) / \mathrm{CIGS}(\mathrm{p}) / \mathrm{Al}\right)$. Hence, in addition to the enhancement in the photovoltaic characteristics of the cell, this heterojunction can substitute the costly annealing step of the Al contact to form the BSF (Back Surface Field).

Typical $\mathrm{J}-\mathrm{V}$ characteristics of this cell under dark and AM1.5 illumination are plot in Fig. 7(b). We obtain an open circuit voltage $\mathrm{V}_{\mathrm{OC}}$ of $470 \mathrm{mV}$ and a short circuit-current density $\mathrm{J}_{\mathrm{SC}}$ of 28 mA.cm ${ }^{-2}$. The series $R_{S}$ and shunt $R_{S h}$ resistances are $8.33 \Omega$ and $1162 \Omega$, respectively. The FF is $28.5 \%$ and the conversion photovoltaic efficiency is $3.75 \%$. These photovoltaic performances are close to those obtained for solar cells prepared by others cost-effective techniques [29-30], leading to conclude that synthesized CIGS films could be an interesting absorber material for bifacial solar cells.

\section{Conclusion}

Highly polycrystalline quaternary $\mathrm{CuIn}_{0.7} \mathrm{Ga}_{0.3} \mathrm{Se}_{2}$ thin film is obtained using a relatively simple and convenient one-step electro-deposition upon galvanostatic mode on monocrystalline silicon substrate. We obtain interesting micro- structural and electrical properties of CIGS absorber layers following Ga incorporation into CIS.

The effect of Ga content on the physical properties of samples was investigated. At $30 \%$ of Ga content in the CIGS material, XRD shows the formation of the single chalcopyrite 
structure phase with a preferential orientation along the (112) direction. The average crystallite size and the lattice parameters are greatly influenced by varying the gallium compositions from 0 to $30 \%$. SEM and EDS analysis prove once again that at the $30 \%$ of Ga proportion, the CIGS layer has a sufficient surface homogeneity covered with agglomerated crystallites (rod-like grains) and nearly stoichiometric composition. From optical measurements, the band gap of $\mathrm{CuIn}_{0.7} \mathrm{Ga}_{0.3} \mathrm{Se}_{2}$ is found to be $1.40 \mathrm{eV}$ which is appropriate for photovoltaic application.

Using Hall effect measurements, we confirm that the CIGS film is of p-type. Furthermore, to a better understanding of the measured AM1.5 J-V characterization of the CIGS $(\mathrm{p}) / \mathrm{c}-\mathrm{Si}(\mathrm{p})$ hetero-junction, we calculate its energy diagram using the Anderson model. Results permit us to conclude that this hetero-junction can play a double role when it is used in a new architecture of c-Si bifacial solar cells $\left(\mathrm{Ag}-\mathrm{Al} / \mathrm{c}-\mathrm{Si}\left(\mathrm{n}^{+}\right) / \mathrm{c}-\mathrm{Si}(\mathrm{p}) / \mathrm{CIGS}(\mathrm{p}) / \mathrm{Al}\right)$. Therefore, in addition to its interesting photovoltaic parameters $\left(\mathrm{V}_{\mathrm{OC}}, \mathrm{J}_{\mathrm{SC}}, \mathrm{R}_{\mathrm{S}}, \mathrm{R}_{\mathrm{Sh}}, \mathrm{FF}\right.$ and $\left.\eta\right)$ as compared to other solar cells prepared by others cost-effective techniques, this hetero-junction can substitute the costly annealing step of the back Al contact when the BSF is formed during the fabrication of c-Si solar cell.

\section{References}

[1] Alvin D. Compaan, Photovoltaics: Clean power for the $21^{\text {st }}$ century, Sol. Energy Mater. Sol. Cells 90 (2006) 2170-2180. https://doi.org/10.1016/j.solmat.2006.02.017

[2] Martin A. Green, Keith Enery, Yoshihiro Hishikawa, Wilkelm Warta, Ewan D. Dunlop, Solar cell efficiency tables (version 47), Progress in Photovoltaic's, 24 (2016) 3-11. https://doi.org/10.1002/pip.2728 
[3] T. Maeda, T. Takeichi, T. Wada, Systematic studies on electronic structures of $\mathrm{CuI}_{n} \mathrm{Se}_{2}$ and the other chalcopyrite related compounds by first principles calculations, Phys. Status Solidi a 203 (2006) 2634-2638. https://doi.org/10.1002/pssa.200669539

[4] A. Duchatelet, T. Sidali, N. Loones, G. Savidand, E. Chassaing, D. Lincot, 12,4\% Efficient $\mathrm{Cu}(\mathrm{In}, \mathrm{Ga}) \mathrm{Se}_{2}$ solar cell prepared from one step electrodeposited $\mathrm{Cu}-\mathrm{In}$-Ga oxide precursor layer, Sol. Energy Mater. Sol. Cells $119 \quad$ (2013) 241-245. https://doi.org/10.1016/j.solmat.2013.07.053

[5] Raghu N. Bhattacharya, Mi-Kyung Oh, Youngho Kim, CIGS-based solar cells prepared from electrodeposited precursor films, Sol. Energy Mater. Sol. Cells 98 (2012) 198202. https://doi.org/10.1016/j.solmat.2011.10.026

[6] H. Sakata, H. Ogawa, Optical and electrical properties of flash-evaporated amorphous $\mathrm{CuInSe}_{2}$ films, Sol. Energy Mater. Sol. Cells 63 (2000) 259-265. https://doi.org/10.1016/S0927-0248(00)00032-5

[7] J. Piekoszewski, J. J. Loferski, R. Beaulieu, J. Beall, B. Roessler, J.Shewchun, Rfsputtered CuInSe ${ }_{2}$ thin films, Sol. Energy Mater. Sol. Cells 2 (1980) 363-372. https://doi.org/10.1016/0165-1633(80)90012-X

[8] M. Krunks, O. Kijatkina, H. Rebane, I. Oja, V. Mikli, A. Mere, Composition of $\mathrm{CuInS}_{2}$ thin films prepared by spray pyrolysis, Thin Solid films 403-404 (2002) 71-75. https://doi.org/10.1016/S0040-6090(01)01534-6

[9] L. Ribeaucourt, G. Savidand, D. Lincot, E. Chassaing, Electrochemical study of onestep electrodeposition of cooper-indium-gallium alloys in acidic conditions as precursor layers for $\mathrm{Cu}(\mathrm{In}, \mathrm{Ga}) \mathrm{Se}_{2}$ thin film solar cells, Electrochimica Acta 56 (2011) 6628-6637. https://doi.org/10.1016/j.electacta.2011.05.033 


\section{Journal Pre-proof}

[10] T. Maeda, T. Takeichi, T. Wada, Systematic studies on electronic structures of $\mathrm{CuInSe}_{2}$ and the other chalcopyrite related compounds by first principles calculations, Phys. Status Solidi a 203 (2006) 2634-2638. https://doi.org/10.1002/pssa.200669539

[11] S. Taunier, J. Sicx-Kurdi, P. P. Grand, A. Chomont, O. Ramdani, L. Parissi, P. Panheleux, N. Naghavi, C. Hubert, M. Ben Farah, J. P. Fauvarque, J. Connolly, O. Roussel, P. Mogensein, E. Mahé, J. F. Guillemoles, D. Lincot, O. Kerrec, $\mathrm{Cu}(\mathrm{In}, \mathrm{Ga})(\mathrm{S}, \mathrm{Se})_{2}$ solar cells and modules by electrodeposition, Thin Solid Films 480-481 (2005) 526-531.

\section{https://doi.org/10.1016/j.tsf.2004.11.200}

[12] Cuevas Andres, The early history of bifacial solar cells, ANU Research Publications, Conference paper (2005). http://hdl.handle.net/1885/84487

[13] H. Saïdi, M. F. Boujmil, B. Durand, J. L. Lazzari and M. Bouaïcha, Elaboration and characterization of $\mathrm{CuInSe}_{2}$ thin films using one step Electrode-position method on silicon substrate for photovoltaic application, Materials Research Express 5 (2018) 016414. https://doi.org/10.1088/2053-1591/aaa604

[14] A. M. Fernandez, R. N. Bhattacharya, Electrodeposition of $\mathrm{CuIn}_{1-\mathrm{x}} \mathrm{Ga}_{\mathrm{x}} \mathrm{Se}_{2}$ precursor films: optimization of film composition and morphology, Thin Solid Films 474 (2005) 10-13. https://doi.org/10.1016/j.tsf.2004.02.104

[15] Sunghun Jung, Sejin Ahn, Jae Ho Yun, Jihye Gwak, Donghwan Kim, Kyunghoon Yoon, Effects of Ga contents on properties of CIGS thin films and solar cells fabricated by co-evaporation technique, Curr. Appl. Phys. 10 (2010) 990-996.

https://doi.org/10.1016/j.cap.2009.11.082

[16] H. Saidi, M. F. Boujmil, B. Durand, M. Bouaïcha, Physical properties of highly crystalline CIS layer prepared using single phase electrodeposition and low temperature RTP annealing, J. Alloys and Compounds 695 (2017) 779-786. 
https://doi.org/10.1016/j.jallcom.2016.09.028

[17] A. Ben Marai, J. Ben Belgacem, Z. Ben Ayadi, K. Djessas, S. Alaya, Structural and optical properties of $\mathrm{CuIn}_{1-\mathrm{x}} \mathrm{Ga}_{\mathrm{x}} \mathrm{Se}_{2}$ nanoparticles synthesized by solvothermal route, J. Alloys and Compounds 658 (2016) 961-966. https://doi.org/10.1016/j.jallcom.2015.10.287

[18] Uwe Holzwarth, Neil Gibson, The Scherrer equation versus the 'Debye-Scherrer equation'. Nature Nanotech.6 (2011) 534. https://doi.org/10.1038/nnano.2011.145

[19] K. Zeaiter, Y.L. linares, and C. L. linarès, Structural and photoluminescence study of the quaternary alloys system CuIn $\left(\mathrm{S}_{\mathrm{x}} \mathrm{Se}_{1-\mathrm{x}}\right)_{2}$, Sol. Energy Mater. Sol. Cells 61 (2000) 313329. https://doi.org/10.1016/S0927-0248(99)00125-7

[20] M. R. Balboul, H. W. Schock, S. A. Fayak, A. Abdel El-Aal, J. H. Werner, A.A. Ramadan, Correlation of structure parameters of absorber layer with efficiency of $\mathrm{Cu}(\mathrm{In}, \mathrm{Ga}) \mathrm{Se}_{2}$ solar cell, Appl. Physics A 92 (2008) 557-563.

https://link.springer.com/article/10.1007\%2Fs00339-008-4630-Z

[21] L. Calvo-Barrio, A. Perez-Rodriguez, J. Alvarez-Carcia, A. Romano-Rodriguez, B. Barcones, J. R. Morante, K. Siemer, I. Luck, R. Klenk, R. Scheer, Combined in-depth scanning Auger microscopy and Raman scattering characterization of $\mathrm{CuInS}_{2}$ polycrystaline films, Vaccum 63 (2001) 315-321. https://doi.org/10.1016/S0042-207X(01)00207-X

[22] In-Hvan choi, Raman spectroscopy of $\mathrm{CuIn}_{1-\mathrm{x}} \mathrm{Ga}_{\mathrm{x}} \mathrm{Se}_{2}$ for in-situ monitoring of the composition ratio, Thin Solid Films 519 (2011) 4390-4393.

https://doi.org/10.1016/j.tsf.2011.02.058

[23] K. Vanheusden, C. H. Seager, W. L. Warren, D. R. Allant and J. A. Voigt, Correlation between photoluminescence and oxygen vacancies in $\mathrm{ZnO}$ phosphors, Appl. Phys. Lett. 68 (1996) 403. https://doi.org/10.1063/1.116699 
[24] C. Guillén, J. Herrero, Optical properties of electrochemically deposited CulnSe ${ }_{2}$ thin films, Sol. Energy Mater. Sol. Cells 23 (1991) 31-452. https://doi.org/10.1016/0165$\underline{1633(91) 90151-\mathrm{A}}$

[25] Cao Jie, Qu Shengchun, Liu Kong and Wang Zhanguo, Effect of bath temperature on the properties of $\mathrm{CuIn}_{\mathrm{x}} \mathrm{Ga}_{1-\mathrm{x}} \mathrm{Se}_{2}$ thin films grown by the electrodeposition technique, $\mathrm{J}$. Semiconductors 31 (2010) Number 8. https://doi.org/10.1088/1674-4926/31/8/083003

[26] M. Bär, W. Bohne, J. Röhrich, E. Strub, S. Lindner, M. C. Lux-Steiner, and Ch.-H. Fischer, Determination of the band gap depth profile of the penternary $\mathrm{Cu}\left(\mathrm{In}_{1-\mathrm{X}}, \mathrm{Ga}_{\mathrm{X}},\left(\mathrm{S}_{\mathrm{Y}} \mathrm{Se}_{1-\mathrm{Y}}\right)_{2}\right.$ chalcopyrite from its composition gradient, J. Appl. Phys. 6 (2004) 3857. https://doi.org/10.1063/1.1786340

[27] Ya-Fen Wu, Hung-Pin Hsu, Hung-Ing Chen, Characterization of the structural and optical properties of $\mathrm{CuIn}_{1-\mathrm{x}} \mathrm{Ga}_{\mathrm{x}} \mathrm{Se}_{2}$; thin films by X-ray diffraction, J. Luminescence 142 (2013) 81-85. https://doi.org/10.1016/j.jlumin.2013.03.046

[28] M. G. Faraj, K. Ibrahim, A. Salhin, Effects of Ga concentration on structural and electrical properties of screen printed-CIGS absorber layers on polyethylene terephthalate, Mat. Sc. Semicond. Process. 15 (2012) 206-213. https://doi.org/10.1016/j.mssp.2012.03.002

[29] Wei Wang, Yu-Wei Su, Chih-Hung Chang, Inkjet printed chalcopyrite $\mathrm{CuIn}_{\mathrm{x}} \mathrm{Ga}_{1-x} \mathrm{Se}_{2}$ thin film solar cells, Sol. Energy Mater. Sol. Cells 95 (2011) 2616-2620. https://doi.org/10.1016/j.solmat.2011.05.011

[30] M. Ganchev, J. Kois, M. Kaelin, S. Bereznev, E. Tzvetkova, O. Volobujeva, N. Stratieva, A. Tiwari, Preparation of $\mathrm{Cu}(\mathrm{In}, \mathrm{Ga}) \mathrm{Se}_{2}$ layers by selenization of electrodeposited Cu-In-Ga precursors, Thin Solid Films 511-512 (2006) 325-327. https://doi.org/10.1016/j.tsf.2005.11.076 


\section{Tables}

Table 1: Structural characteristics of the quaternary alloy $\mathrm{Cu}\left(\mathrm{In}_{1-\mathrm{x}}, \mathrm{Ga}_{\mathrm{x}}\right) \mathrm{Se}_{2}$ thin films for different values of $\mathrm{x}$, derived from XRD analysis.

Table 2: Elemental composition of EDS patterns of CIGS thin films at different Ga contents. 
Table 1: Structural characteristics of the quaternary alloy $\mathrm{Cu}\left(\mathrm{In}_{1-\mathrm{x}}, \mathrm{Ga}_{\mathrm{x}}\right) \mathrm{Se}_{2}$ thin films for different values of $\mathrm{x}$, derived from XRD analysis.

\begin{tabular}{|c|c|c|c|c|c|c|c|}
\hline \multirow[t]{2}{*}{$\mathbf{x}$} & \multirow[t]{2}{*}{$\begin{array}{c}\text { Bragg angle } \\
2 \theta\left({ }^{\circ}\right)\end{array}$} & \multirow[t]{2}{*}{ FWHM $\left(^{\circ}\right)$} & \multirow[t]{2}{*}{$D(\mathbf{n m})$} & \multicolumn{2}{|c|}{$\begin{array}{c}\text { Lattice } \\
\text { parameters } \\
(\AA)\end{array}$} & \multirow{2}{*}{$\begin{array}{l}\text { Distorsion } \\
\qquad \mu=c / a\end{array}$} & \multirow[t]{2}{*}{$\begin{array}{l}\text { Strain } \\
\left(\varepsilon \times 10^{-2}\right.\end{array}$} \\
\hline & & & & $\mathbf{a}$ & c & & \\
\hline 0.0 & 26.50 & 0.121 & 67.30 & 5.78 & 11.61 & 2.007 & 0.224 \\
\hline 0.1 & 26.75 & 0.150 & 53.82 & 5.76 & 11.55 & 2.005 & 0.275 \\
\hline 0.2 & 26.95 & 0.152 & 53.15 & 5.74 & 11.50 & 2.003 & 0.277 \\
\hline 0.3 & 27.15 & 0.098 & 82.50 & 5.73 & 11.47 & 2.001 & 0.177 \\
\hline
\end{tabular}


Table 2: Elemental composition of EDS patterns of CIGS thin films at different Ga contents.

\begin{tabular}{c|c|c|c}
\hline $\mathbf{x}$ & $\begin{array}{c}\text { Precursor } \\
\text { composition } \\
(\%)\end{array}$ & $\begin{array}{c}\text { EDS estimated composition } \\
(\text { Molar ratio } \\
\text { Cu: In: Ga: } \text { Se })\end{array}$ & $\begin{array}{c}\mathbf{C u}+\mathbf{I n + G a + S e = 1} \\
(\text { Theoritecally 100\%) }\end{array}$ \\
\hline 0 & $1 / 1 / 0 / 2$ & $26.14 / 22.83 / 0.00 / 51.03$ & 1.04 \\
\hline 10 & $1 / 0.9 / 0.1 / 2$ & $25.12 / 22.71 / 3.72 / 48.45$ & 0.93 \\
\hline 20 & $1 / 0.8 / 0.2 / 2$ & $24.30 / 20.33 / 5.80 / 49.57$ & 0.98 \\
\hline 30 & $1 / 0.7 / 0.3 / 2$ & $25.57 / 15.41 / 8.54 / 50.48$ & 1.02 \\
\hline
\end{tabular}




\section{Figures caption}

Fig. 1: XRD patterns of $\mathrm{Cu}\left(\mathrm{In}_{1-\mathrm{x}}, \mathrm{Ga}_{\mathrm{x}}\right) \mathrm{Se}_{2}$ layers prepared by one-step electrodeposition onto silicon (Si (100)) substrate at different Ga contents.

Fig. 2: Variation of relative intensity of the main peak (112) as a function of $x=\frac{G a}{I n+G a}$ ratio.

Fig. 3: The dependence of the lattice parameters $a$ and $c$ on the Ga contents.

Fig. 4: SEM images of top surface of electrodeposited $\mathrm{Cu}\left(\mathrm{In}_{1-\mathrm{x}} \mathrm{Ga}_{\mathrm{x})} \mathrm{Se}_{2}\right.$ layers on Si before and after Ga doping: (a) Undoped CIS film ( $\mathrm{x}=0$ ); (b), (c) and (d) doped samples at $x=0.1, x$ $=0.2$ and $x=0.3$, respectively.

Fig. 5: Typical EDS spectrum of $\mathrm{Cu}\left(\mathrm{In}_{1-\mathrm{x}} \mathrm{Ga}_{\mathrm{x}}\right) \mathrm{Se}_{2}$ thin films: (a) ternary CIS and (b) quaternary $\mathrm{Cu}\left(\mathrm{In}_{0.7} \mathrm{Ga}_{0.3)} \mathrm{Se}_{2}\right.$ films.

Fig. 6: Plot of $(F(R) h v)^{2}$ vs. (hv) using the Kubelka-Munk approximation for CIGS thin films deposited on silicon substrates with different Ga composition.

Fig. 7: (a): Simulated energy diagram of the CIGS(p)/c-Si(p) heterojunction using the Anderson model. (b): Dark and AM1.5 illumination J-V curves of the fabricated Al/ Cu $\left(\operatorname{In}_{0.7}\right.$ $\mathrm{Ga}_{0.3)} \mathrm{Se}_{2} / \mathrm{c}-\mathrm{Si}: \mathrm{p} / \mathrm{Al}$ hetero-junction solar cells. 


\section{Figures}
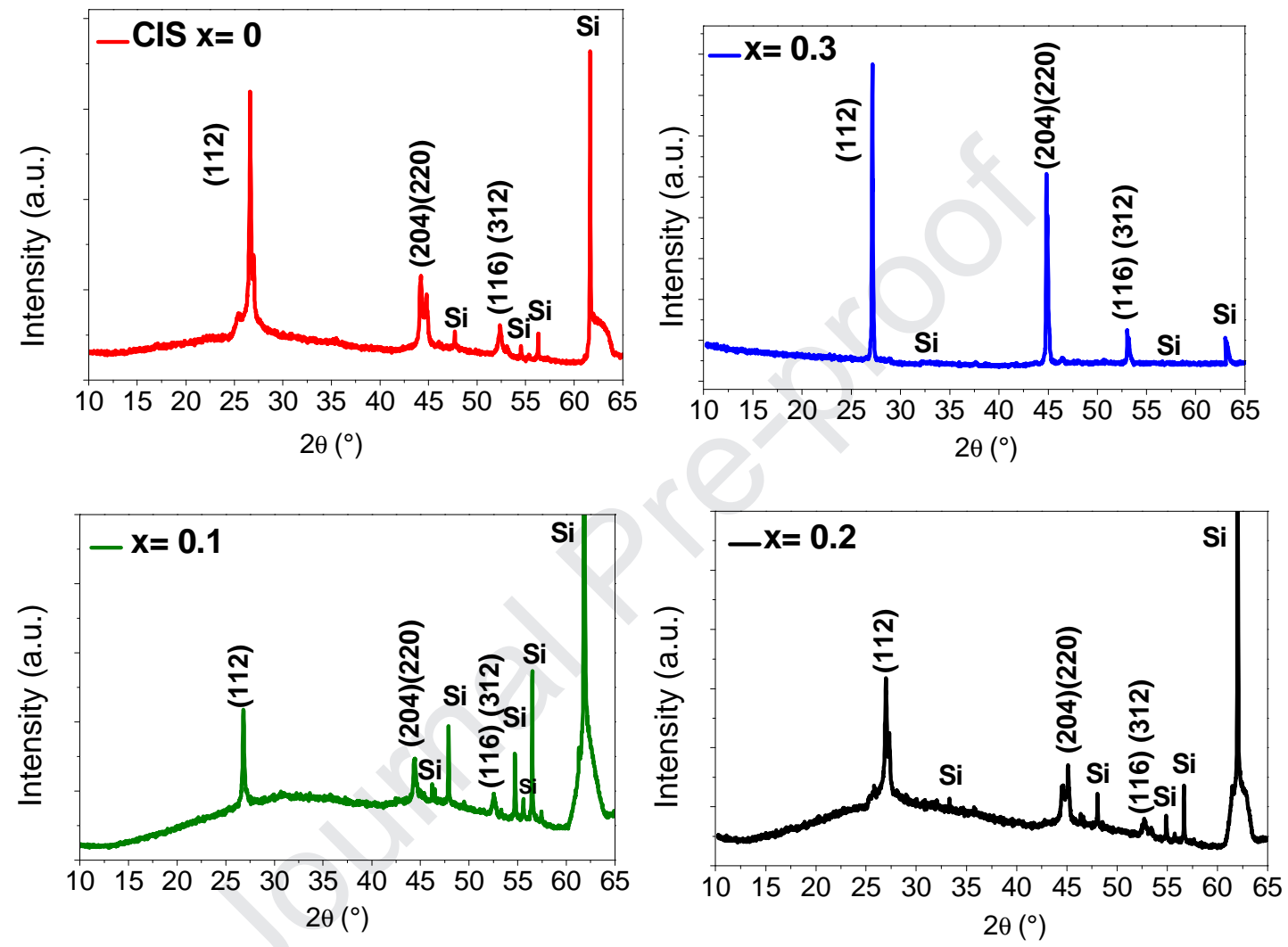

Fig. 1: XRD patterns of $\mathrm{Cu}\left(\mathrm{In}_{1-\mathrm{x}}, \mathrm{Ga}_{\mathrm{x}}\right) \mathrm{Se}_{2}$ layers prepared by one-step electrodeposition onto silicon ( $\mathrm{Si}(100))$ substrate at different Ga contents. 


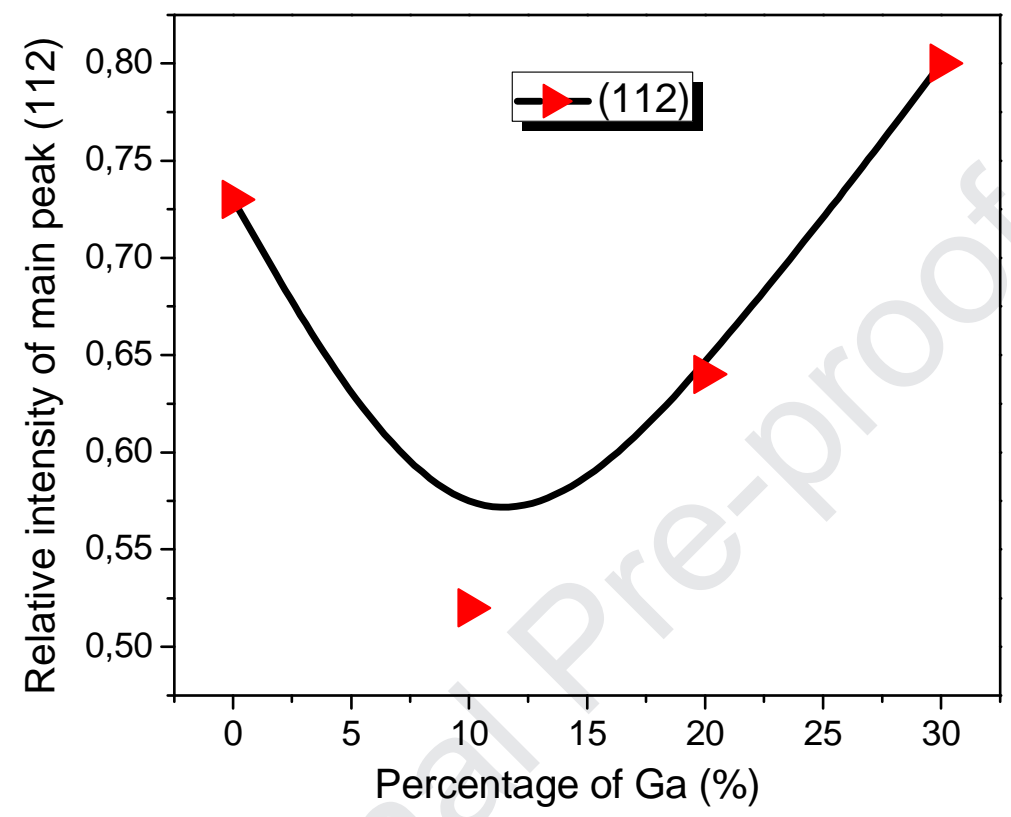

Fig. 2: Variation of relative intensity of the main peak (112) as a function of $x=\frac{G a}{I n+G a}$ ratio. 


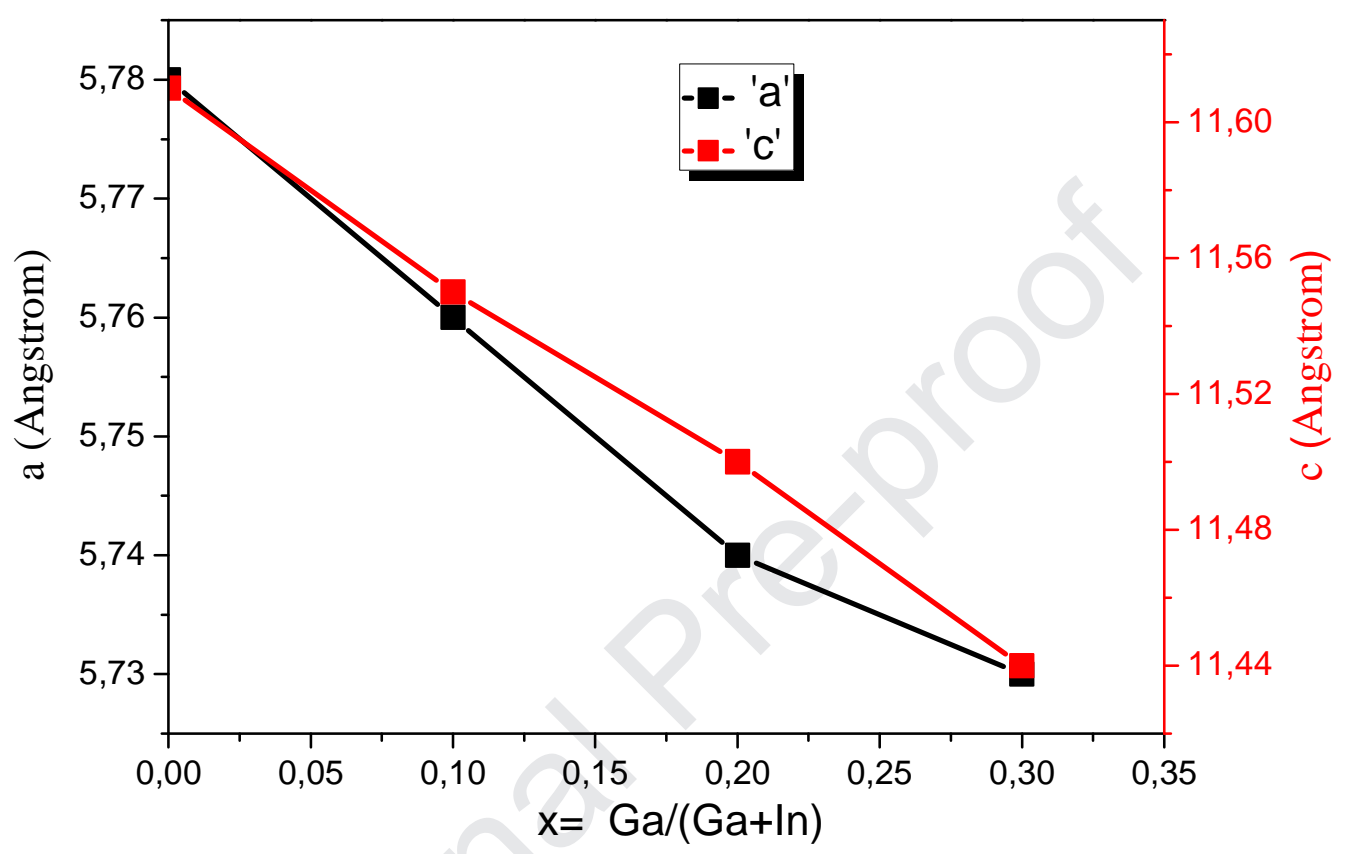

Fig. 3: The dependence of the lattice parameters $a$ and $c$ on the Ga contents. 

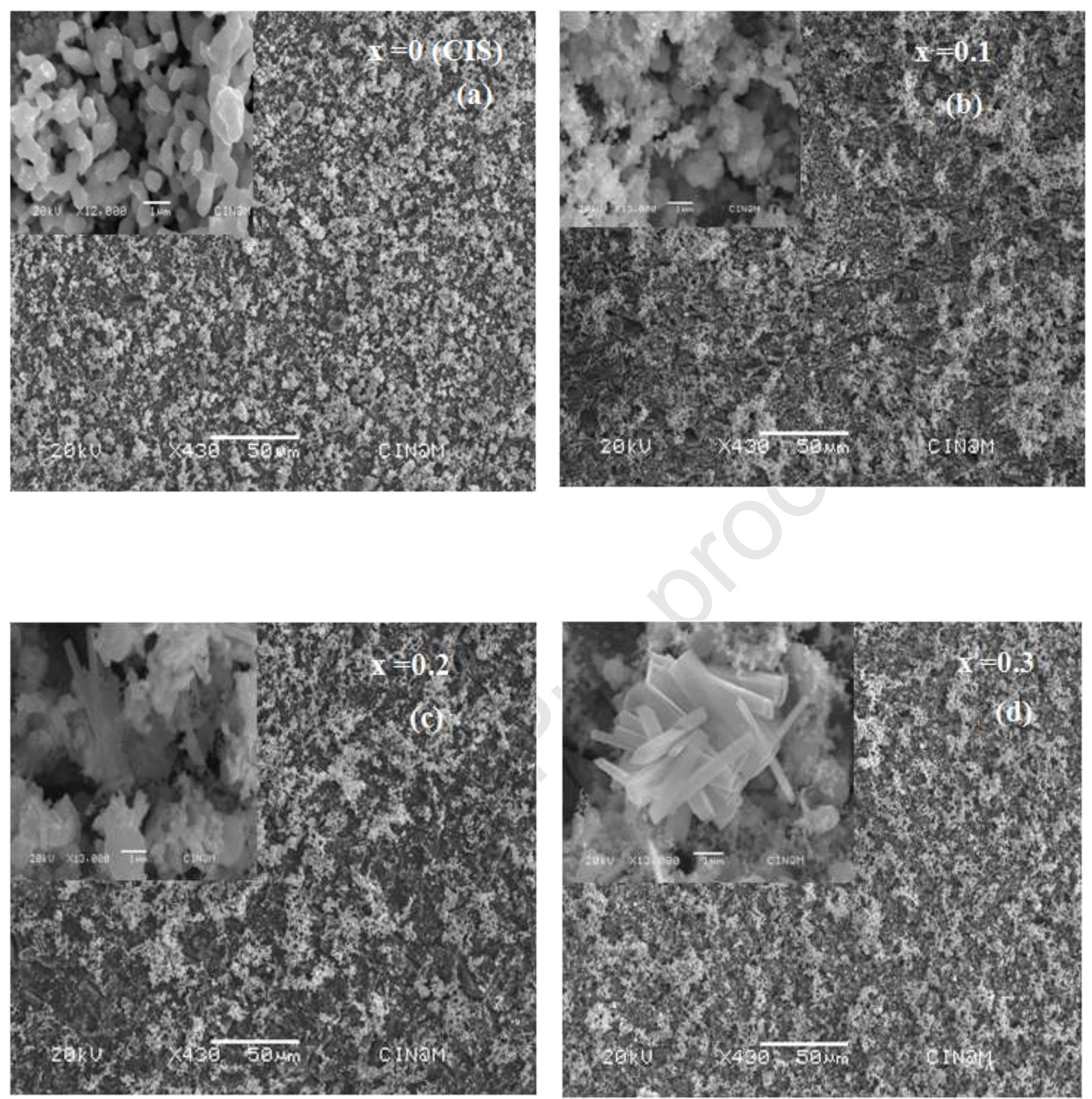

Fig. 4: SEM images of top surface of electrodeposited $\mathrm{Cu}\left(\mathrm{In}_{1-\mathrm{x}} \mathrm{Ga}_{\mathrm{x})} \mathrm{Se}_{2}\right.$ layers on $\mathrm{Si}$ before and after Ga doping: (a) Undoped CIS film (x=0); (b), (c) and (d) doped samples at $x=0.1, x$ $=0.2$ and $x=0.3$, respectively. 

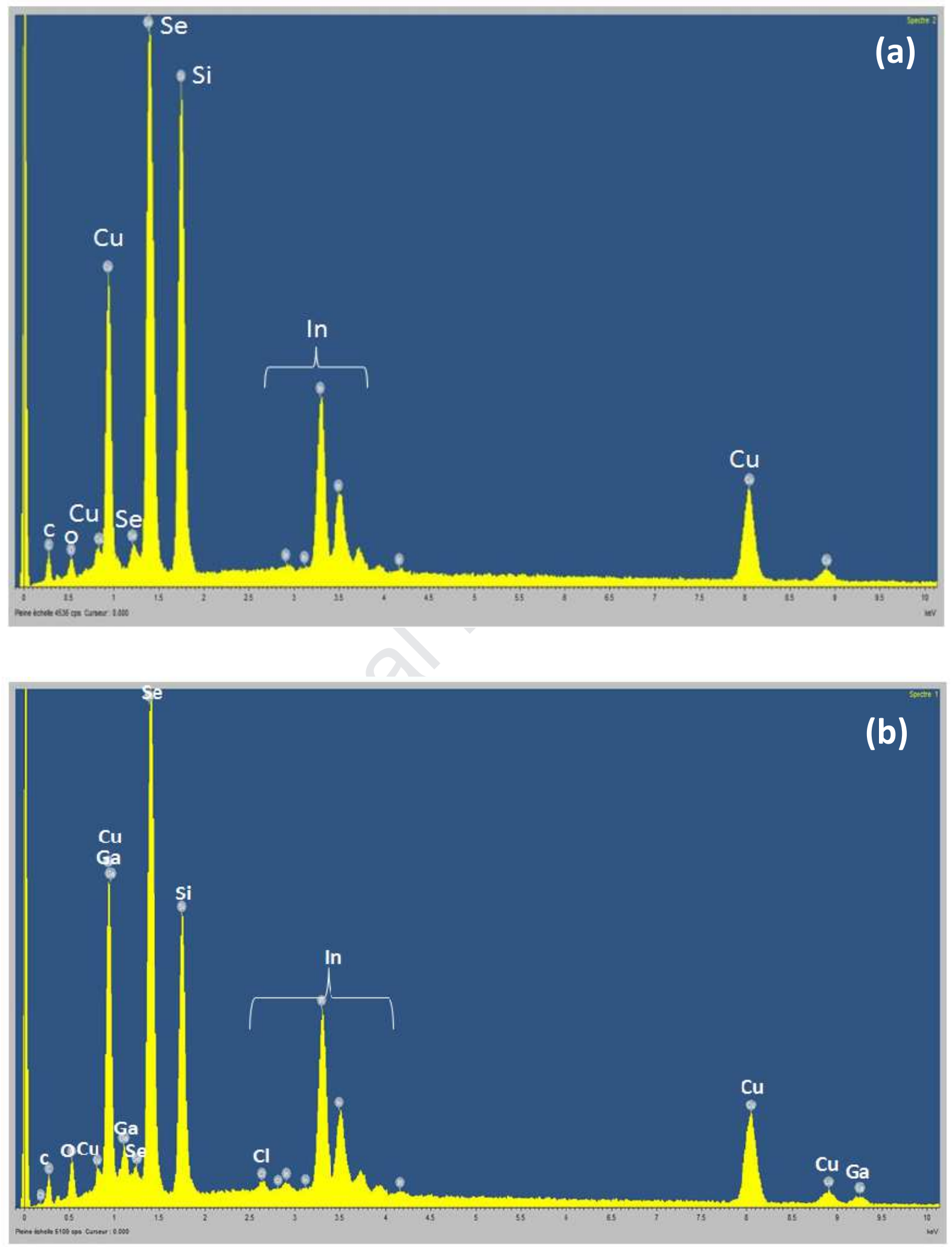

Fig. 5: Typical EDS spectrum of $\mathrm{Cu}\left(\mathrm{In}_{1-\mathrm{x}} \mathrm{Ga}_{\mathrm{x}}\right) \mathrm{Se}_{2}$ thin films: (a) ternary CIS and (b) quaternary $\mathrm{Cu}\left(\mathrm{In}_{0.7} \mathrm{Ga}_{0.3)} \mathrm{Se}_{2}\right.$ films. 


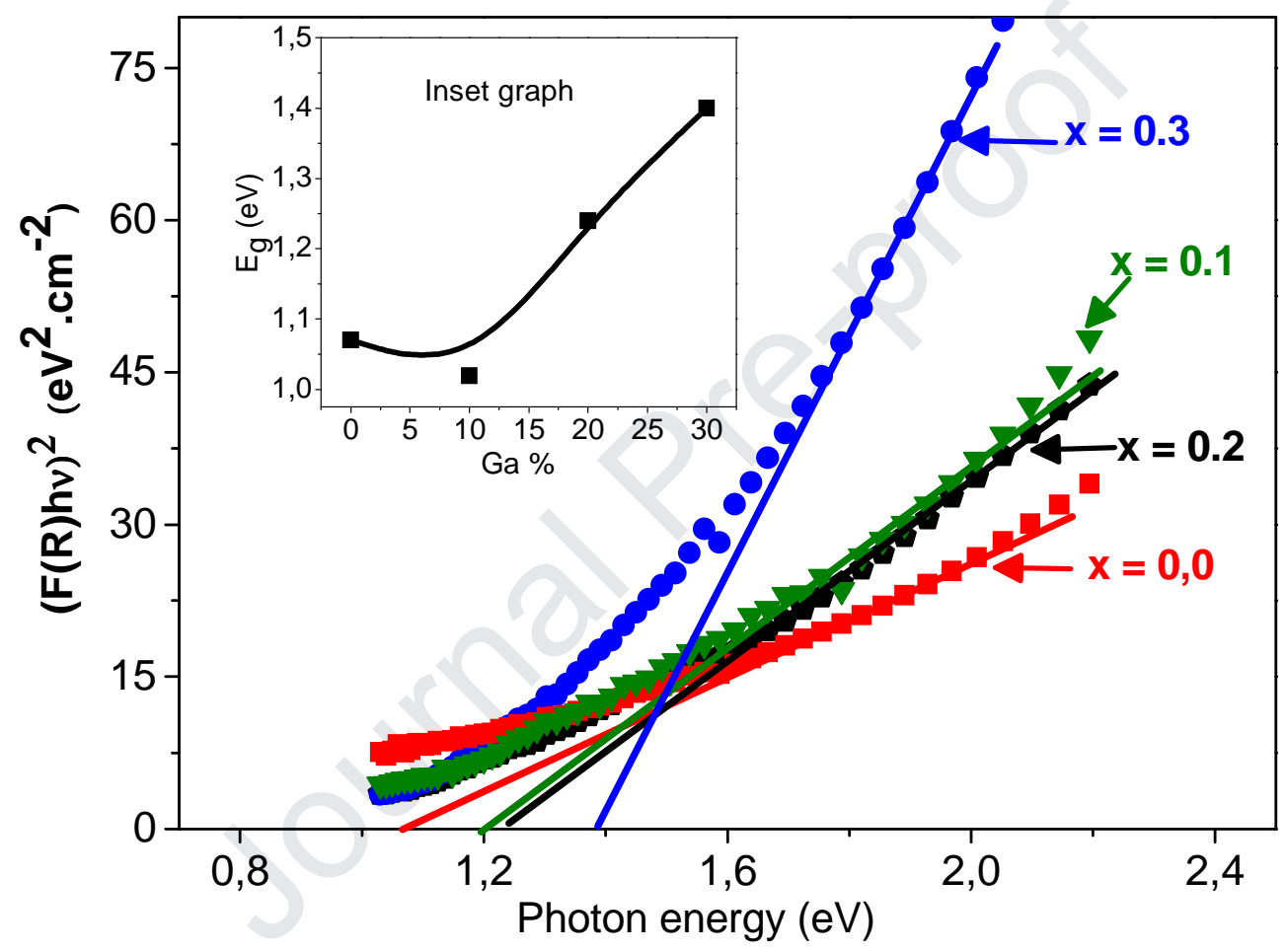

Fig. 6: Plot of $(\mathrm{F}(\mathrm{R}) \mathrm{hv})^{2}$ vs. (hv) using the Kubelka-Munk approximation for CIGS thin films deposited on silicon substrates with different Ga composition. 
(a)

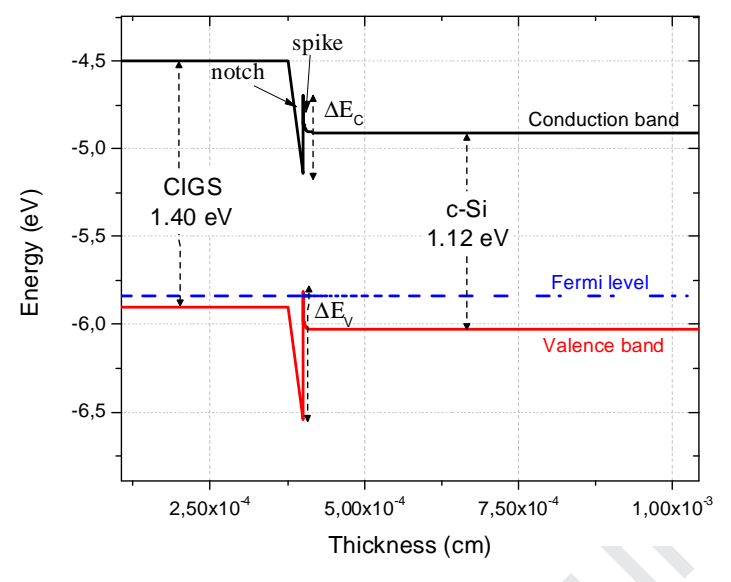

(b)

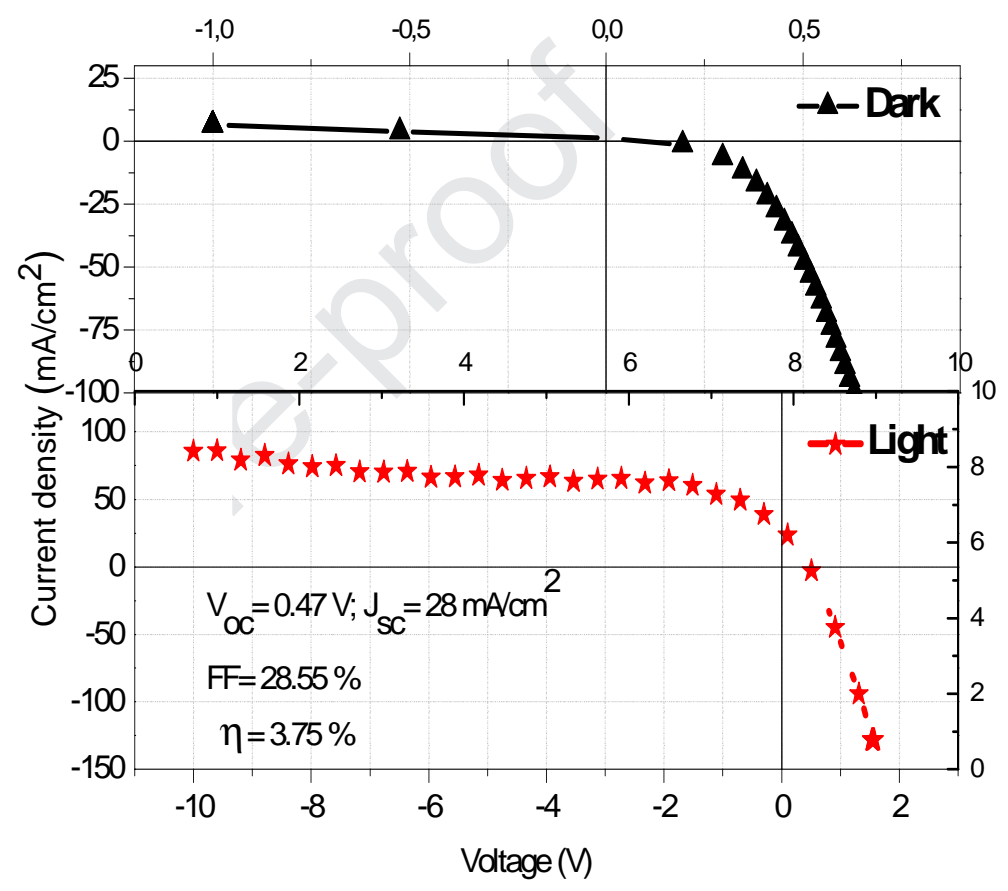

Fig. 7: (a): Simulated energy diagram of the CIGS(p)/c-Si(p) heterojunction using the Anderson model. (b): Dark and AM1.5 illumination J-V curves of the fabricated Al/ Cu $\left(\operatorname{In}_{0.7}\right.$ $\mathrm{Ga}_{0.3)} \mathrm{Se}_{2} / \mathrm{c}-\mathrm{Si}: \mathrm{p} / \mathrm{Al}$ hetero-junction solar cells. 


\section{Highligths}

- Highly polycrystalline CIGS film is electro-deposited on c-Si to form CIGS/c-Si hetero-junction.

- AM1.5 J-V performed on the $\mathrm{CuI}_{0.7} \mathrm{G}_{0.3} \mathrm{Se}_{2} / \mathrm{c}-\mathrm{Si}$ hetero-junction reveals interesting photovoltaic parameters with an efficiency of $3.75 \%$.

- Using the Anderson model, we show that the CIGS/c-Si hetero-junction could play a dual in a new architecture solar cell. 